\title{
O Direito à Educação e a Constituição de 1988: O Embate entre a Norma e a sua Efetivação
}

\author{
Bruna Chicaroni Leonardo
}

\begin{abstract}
RESUMO
Os estudos e discussões em face do direito à educação mostram-se importantes à medida que colaboram para a compreensão de tal direito que se revelou, com o passar do tempo, essencial à formação humana. A Constituição Federal de 1988, reconhecendo a indispensabilidade de tal direito, preocupou-se em trazê-lo como um direito social e dispôs, principalmente, em seus artigos de 205 a 214, sobre suas finalidades, os órgãos responsáveis por sua efetivação, bem como, definiu alguns recursos disponibilizados ao cumprimento de tal direito. Assim, o presente trabalho almeja estudar as normas constitucionais que dispõem sobre o direito à educação, partindo da análise de sua eficácia e efetividade, para que, com base em tal estudo, seja possível alcançar dados suficientes a fim de se discutir as contradições existentes entre tais normas e a efetivação do direito à educação na atualidade brasileira.
\end{abstract}

Palavras chaves: Direito à Educação; Norma Constitucional; Efetividade; Ações Constitucionais; Reserva do Possível.

\section{ABSTRACT \\ The right to education and the constitution of 1988: the brunt between the law and its effectuation}

The studies and discussions about the right to education appear to be very important in the sense that they collaborate on the understanding of the fact that this right has revealed to be essential to the human formation. The Federal Constitution of 1988 recognizing the indispensability of this right, has categorized it as a social right and stated Specially the articles 205 and 214 the purposes of this social right, the organisms responsible for its effectuation as well as the resources available for the accomplishment of such right. Therefore, the present work aims to study the constitutional norms that state the right to education starting from the analysis of its effectiveness and efficiency, so based on this study, it becomes possible to reach sufficient data in order to discuss the existent contradictions between such rules and the effectuation of the right to education in the current Brazil.

Keywords: right to education; constitutional norms; effectiveness; constitutional actions; reserve of possible 


\section{INTRODUÇÃO}

Desde os séculos mais distantes até a atualidade, o direito à educação, em seu sentido amplo, mostrou-se como um bem de essencial valor aos seres humanos. Na realidade, com a evolução humana, a educação que se baseava apenas em ensinamentos familiares, como garantia de sobrevivência, adquiriu complexidade a fim de acompanhar as necessidades de cada homem como individuo, e da sociedade como um todo.

Ganhou força principalmente na Idade Contemporânea, já que é reconhecida como um direito civilizado, ou seja, desenvolveu-se juntamente com os povos civilizados mais recentes, haja vista que nas sociedades primitivas a educação era mais consuetudinária e passava de pais para filhos.

Notou-se, a partir da era Contemporânea, uma transformação na educação que se tornou mais concreta e sistemática deixando de ser algo restrito ao ambiente familiar. Nesta época, surgiu um grande número de instituições educacionais criadas com o intuito de complementar a atividade educacional ao passo que o acervo cultural necessário para que as pessoas se integrassem na sociedade passou a se expandir, tornando os ensinamentos familiares insuficientes para suprir tal demanda. ${ }^{1}$

A Grécia consagrou-se como pioneira das tendências educacionais e tal fato deveu-se aos grandes filósofos gregos da idade clássica como Sócrates, Platão e Aristóteles. Este, por sua vez, em uma de suas mais importantes obras A Política, defendeu que a educação é o meio adequado para que todos dentro de uma cidade alcancem a virtude, "desenvolvendo harmônica e hierarquicamente todas as faculdades espirituais, intelectuais e físicas do cidadão".2

As idéias desenvolvidas na Grécia foram apenas o primeiro passo para o reconhecimento da educação ao longo dos tempos. Uma análise do processo histórico da humanidade poderá mostrar que, principalmente, no final da Idade Média notou-se uma crescente presença da educação, das instituições educacionais, mais conhecidas como escolas, de métodos e didáticas distintas que possibilitaram a adaptação da educação a cada época vivida pela humanidade de

\footnotetext{
${ }^{1}$ BASTOS, Celso Ribeiro; MARTINS, Ives Gandra. Comentários à constituição federal do Brasil. São Paulo: Saraiva, 1998.v.8.p.411.

${ }^{2}$ ARISTÓTELES. A política. São Paulo: Martins Fontes,1998.p.65.
} 
maneira a propiciar a formação de milhares de homens para a realidade na qual estavam inseridos ${ }^{3}$.

Ao longo dos séculos a educação, que por sua vez tem como principal objetivo levar o conhecimento, mostrou-se como um dos meios mais eficazes de ajudar o homem a compreender o mundo, para nele atuar.

No Brasil, desde 1824, a educação tornou-se direito reconhecido pelo ordenamento jurídico sendo garantida, ainda que de forma imatura, pela Constituição Política do Império do Brasil, que foi a primeira Constituição deste país. As demais Constituições brasileiras também se posicionaram sobre o tema. Entretanto, foi com a Constituição Federal de 1988 que o direito fundamental à educação, tornou-se expressamente um direito social, reconhecido em seu artigo sexto.

Quando a Constituição Federal de 1988 enumerou alguns direitos intitulados sociais, buscou zelar pela existência de uma sociedade desenvolvida, justa e menos desigual, características que constituem os objetivos fundamentais da República Federativa do Brasil, que foi definida pelo artigo primeiro desta mesma carta como um Estado Democrático de Direito. Este, por sua vez, surge em um momento de valorização dos direitos humanos fundamentais (período pós-Segunda Guerra Mundial) que em linhas gerais, diante de seu conteúdo, consagraram-se como garantidores da dignidade da pessoa humana ${ }^{4}$.

Embora a Constituição Federal de 1988 não tenha explicitamente considerado em seu artigo quinto a educação como um direito fundamental, essa pode ser entendida "como extensão do direito à vida, já que a finalidade básica da educação é formar para a liberdade, para a cidadania e para a dignidade" 5 , como defendido pela professora Maria Garcia, fatores estes capazes de influenciar de forma direta na vida em sociedade.

Contudo, mesmo perante o status de fundamentalidade adquirido pelo direito social à educação, optou o constituinte por estabelecer outras normas constitucionais cujo principal objetivo era garantir o acesso a esse direito, aqui tido em seu sentido amplo, impondo ao Estado, à família e à sociedade o dever de promovê-lo e incentivá-lo "visando ao pleno desenvolvimento

\footnotetext{
${ }^{3}$ É notável que em um primeiro momento o acesso à educação era, ainda, privilégio de poucos, mas esse fato não deve descaracterizar o reconhecimento que tal direito foi recebendo ao longo dos anos.

${ }^{4}$ Cabe destacar que as considerações históricas feitas sobre a evolução do direito à educação na introdução do presente artigo, tiveram como base os estudos de Celso Ribeiro Bastos e Ives Gandra Martins, na obra Comentários à constituição federal do Brasil, já devidamente citada.

${ }^{5}$ GARCIA, Maria. "A nova lei de diretrizes e bases da educação nacional”. In: Revista dos Tribunais.Cadernos de Direito Constitucional e Ciência Política .n.23. p. 57.
} 
da pessoa, seu preparo para o exercício da cidadania e sua qualificação para o trabalho", como prevê o artigo 205 da atual Constituição brasileira.

Desta forma, a Constituição Federal garante o acesso ao ensino obrigatório, consagrandoo como um direito público subjetivo (artigo 208, parágrafo primeiro), e onera o Estado com o dever de torná-lo efetivo. No entanto, esta efetivação que busca o artigo 208 da Constituição Federal é realizada muitas vezes de forma inadequada e descomprometida com outras normas constitucionais que também tratam da garantia do direito à educação.

Percebe-se, a partir disso, a existência de um conflito entre aquilo que é imposto pela realidade e aquilo que traz a norma constitucional como algo a ser atendido pelo Estado. Esta tensão entre as normas constitucionais e a realidade se agrava com a presença de fatores extrajurídicos, tais como questões políticas, econômicas e sociais que criam, de certa maneira, barreiras à efetivação de algumas normas presentes na Constituição Federal, entre elas as que tratam do direito à educação. Este dissenso observado entre as circunstâncias da realidade fática e as pretensões de normatividade do Constituinte contribuiu para o aparecimento de valiosos estudos que buscaram repensar o Direito Constitucional e a forma de interpretação e aplicabilidade das normas constitucionais.

Assim, notou-se a necessidade de que a Constituição Federal fosse interpretada e aplicada de acordo com a realidade histórico-cultural na qual se insere ${ }^{6}$, fato este de grande importância para que sejam realizados concretamente seus preceitos.

No Capitulo III, Seção I, da Constituição Federal de 1988, encontra-se um complexo de normas que visam garantir que o acesso à educação se dê de forma democrática. Todavia, a realidade mostra que muitas dessas normas, principalmente aquelas que são consideradas partes essenciais ao direito fundamental à educação, não se efetivam e prejudicam desta forma o acesso à escola bem como, a qualidade do ensino oferecido a milhares de crianças e jovens.

Desta maneira, as preocupações não se resumem ao simples acesso; não basta entrar e permanecer na escola, é preciso que o estudante aprenda a criar, inovar, sugerir, pensar e atuar de modo construtivo. Por isso, a própria Constituição traz algumas normas que tratam da forma

\footnotetext{
${ }^{6}$ Acerca deste fato KONRAD HESSE defende a necessidade de que haja uma sintonia entre "a realidade histórica e a superestrutura institucional", para que a Constituição se realize de forma juridicamente criadora, partindo de um contexto histórico concreto. In: A força normativa da constituição. Porto Alegre: Sérgio Antonio Fabris Editor, 1991. p.11.
} 
como o ensino deve ser ministrado bem como, dos objetivos por ele visados, além de reconhecer a necessidade de ser o direito à educação complementado por leis infraconstitucionais, com o escopo de que ele seja precursor de uma sociedade desenvolvida e mais justa.

Todavia, os dados da atualidade mostram que a forma como se efetiva o direito à educação, principalmente a fundamental, não é, na maioria dos casos, compatível com as pretensões das normas constitucionais, podendo tal fato colaborar para que o ensino ministrado seja de baixa qualidade e criador de pequenos progressos sociais.

Mesmo perante o grande número de estudos e opiniões já expressos a respeito da educação brasileira, torna-se importante, principalmente diante das fortes e constantes críticas as quais enfrenta, pensá-la como um direito fundamental garantido constitucionalmente. Destarte, o momento mostra-se propício para que se promova um estudo jurídico sobre um assunto de suma importância na atualidade brasileira: o direito à educação. Neste trabalho, o tema será estudado a partir da análise de normas constitucionais, com a pretensão de se questionar os entraves à concretização deste direito.

É relevante, pois, analisar o direito à educação, pensando na Constituição Federal, no valor de suas normas e na sua efetividade, bem como nas responsabilidades do Estado diante deste direito.

Assim, será possível discutir sobre o objeto principal deste estudo, ou seja, a efetivação do direito à educação, diante de sua fundamentalidade e importância como contribuidor da formação de cidadãos, além de "levar a sério" - lembrando Ronald Dworkin - o reconhecimento de tal direito que mesmo positivado, necessita ser repensado pela sociedade e pelo governo brasileiro.

\section{A educação como um direito social: apontamentos sobre a fundamentalidade deste direito na Constituição brasileira de 1988}

Para tratar do direito à educação e, principalmente, para discutir sobre sua aplicabilidade e efetivação, é importante esclarecer alguns pontos relevantes sobre a natureza de tal direito.

A partir do século XX, houve uma maior consideração estatal aos chamados direitos fundamentais, que segundo o jurista português Joaquim José Gomes de Canotilho, "são direitos do homem $^{7}$ jurídico - institucionalmente garantidos e limitados espacio - temporalmente" 8 .

\footnotetext{
${ }^{7}$ Canotilho difere em sua obra os "direitos fundamentais" dos " direitos humanos". Para o autor estes "são direitos validos para todos os povos, em todos os tempos", saem da própria natureza humana, por isso são invioláveis,
} 
Assim, são eles direitos essenciais à vida humana reconhecidos juridicamente pelo Estado dentro de uma determinada época. Compactua desse mesmo entendimento Ingo Wolfgang Sarlet. ${ }^{9}$

Entretanto, para tal estudo não é o bastante apenas apontar a natureza dos direitos fundamentais. É preciso também discutir sobre sua aplicação na realidade para a qual foram positivados. Para Canotilho, o Direito Constitucional positivo é um sistema dentro do qual se encontram, entre outros institutos, as garantias, os direitos e as liberdades, e também os direitos sociais, econômicos e culturais ${ }^{10}$. Ambos os grupos são formas de realização dos direitos fundamentais acolhidos pelo Estado, cada qual com suas particularidades.

As garantias, os direitos e as liberdades apresentam-se como "princípios jurídicos imediatamente eficazes e atuais", pois, independem do legislador para serem aplicados, são de aplicabilidade direta por força da Constituição ${ }^{11}$. Entretanto, mesmo com a eficácia imediata alguns direitos, garantias e liberdades dependem, em determinados casos, do legislador para torná-los plenamente realizáveis. Como exemplo, o direito de igualdade de todos perante a lei, como assegura o artigo $5^{\circ}$ caput da Constituição Federal brasileira. Este é um direito plenamente eficaz, pois é uma garantia de igualdade aos homens em sociedade. Mas, como se procede a sua aplicação na vida do homem em sociedade ${ }^{12}$

Conforme ensina Canotilho, os direitos, as garantias e as liberdades:

\begin{abstract}
Não são simples norma normarum, mas norma normata, isto é, não são meras normas para a produção de outras normas, mas sim normas diretamente reguladoras de relações jurídico materiais. Lembremos que se esta idéia de aplicabilidade direta significa uma normatividade qualificada, nem sempre as liberdades, os direitos e as garantias dispensam a concretização através das entidades legiferantes. Por outras palavras: a aplicabilidade direta das normas consagradoras de direitos, liberdades e garantias não implica sempre, de forma automática, a transformação destes em direitos subjetivos, concretos e definitivos ${ }^{13}$
\end{abstract}

intemporais e universais. Embora muitos considerem sinônimas as expressões citadas, os direitos humanos independem de qualquer vinculação à ordem Constitucional positiva de um Estado. A diferença é sutil, pois, muitos direitos humanos encontram-se positivados como direitos fundamentais - Cf. CANOTILHO, Joaquim José Gomes de. Direito constitucional e teoria da constituição. 3. ed. Coimbra - Portugal: Almedina,1998.p.369.

${ }^{8}$ CANOTILHO, Joaquim Jose Gomes de. Direito constitucional e teoria da constituição. 3.ed. Coimbra -Portugal: Almedina,1998. p.369.

${ }^{9}$ SARLET, Ingo Wolfgang. A eficácia dos direitos fundamentais. Porto Alegre: Livraria do Advogado, 1998. p.29.

${ }^{10}$ CANOTILHO, Joaquim José Gomes de. Direito constitucional e teoria da constituição. 3. ed. Coimbra -Portugal: Almedina, 1998.p. 374 e ss.

${ }^{11}$ CANOTILHO, Joaquim José Gomes de. Direito constitucional e teoria da constituição. 3. ed. Coimbra -Portugal: Almedina, 1998. p. 412.

${ }^{12}$ Este é um tema complexo e amplo. Será tratado no item três deste trabalho em face de sua extensão.

${ }^{13}$ CANOTILHO, Joaquim José Gomes de. Direito constitucional e teoria da constituição. 3. ed. Coimbra -Portugal: Almedina, 1998 .p. 412. 
Desta forma, muitos direitos, garantias e liberdades, mesmo que sejam classificados em sentido amplo como direitos self executing ${ }^{14}$ necessitam para sua concretização da ação do legislador. Apesar desta necessidade, não perdem sua função principal que é a defesa de certos direitos fundamentais, "auto-impondo-se como direitos negativos diretamente conformadores de um espaço subjetivo de distanciação e autonomia com o correspondente dever de abstenção ou proibição de agressão por parte dos destinatários passivos, públicos e privados" ${ }^{15}$

No momento em que tal função de defesa se converter em necessidade de prestação do Estado, não se fala mais em direitos, garantias e liberdades, mas sim em direitos econômicos, sociais e culturais, que são também formas de concretização dos direitos fundamentais. Estes, na visão de Canotilho, são dotados de algumas funções, dentre elas a função de prestação social. Assim, dos direitos fundamentais positivados nasce o direito do particular em obter algo através do Estado, por exemplo: a educação. Este algo é o que pode ser chamado de direitos econômicos, sociais e culturais. ${ }^{16}$

O direito à educação é inegavelmente uma extensão do direito à vida, haja vista que sua finalidade é proporcionar o desenvolvimento da personalidade humana, é tornar os homens mais íntegros aprimorando sua capacidade crítica, e oferecendo aos mesmos possibilidades de participação na sociedade na qual estão inseridos. Segundo o entendimento de Renato Alberto Teodoro Di Dio, citado por Elias de Oliveira Motta, "quando se fala em preservação da vida a intenção é torná-la digna, plena, produtiva e feliz. Se assim é, a educação apresenta-se como condição dessa dignidade, plenitude, produtividade e felicidade" ${ }^{17}$. Por esse motivo, o legislador constituinte de 1988 a classificou como um direito social intimamente ligado ao direito à vida, e imputou ao Estado a obrigação de cumpri-lo.

José Afonso da Silva classifica os diretos sociais como:

Uma dimensão dos direitos fundamentais do homem; são prestações positivas proporcionadas pelo Estado direta ou indiretamente, enunciados em normas constitucionais, que possibilitam melhores condições de vida aos mais fracos, direitos

\footnotetext{
${ }^{14}$ As normas self executing são consideradas doutrinariamente como normas prontas para serem aplicadas, ou seja, sua aplicação independe de qualquer outra lei.

${ }^{15}$ CANOTILHO, Joaquim José Gomes de. Direito constitucional e teoria da constituição. 3. ed. Coimbra -Portugal: Almedina, 1998.p.367.

${ }^{16}$ CANOTILHO, Joaquim José Gomes de. Direito constitucional e teoria da constituição. 3. ed. Coimbra -Portugal: Almedina, 1998.p.378 e 379.

${ }^{17}$ MOTTA, Elias de Oliveira. Direito educacional e educação do século XXI: com comentários à nova lei de diretrizes e bases da educação nacional. Brasília: UNESCO,1997.p.76 e 77.
} 
que tendem a realizar a igualdade de situações sociais desiguais. São, portanto, direitos que se ligam ao direito da igualdade. Valem como pressupostos do gozo de direitos individuais na medida em que criam condições materiais mais propícias ao auferimento da igualdade real, o que, por sua vez, proporciona condição mais compatível com o exercício da liberdade. ${ }^{18}$

Portanto, ao inserir no artigo sexto da Constituição Federal de 1998 o direito à educação, o legislador buscou garantir a realização de tal direito pelo Estado e afirmou sua natureza como direito fundamental ao homem já que, como ressalta Ingo Wolfgang Sarlet: "Direitos fundamentais são os direitos do ser humano reconhecidos e positivados na esfera do direito constitucional positivo de um determinado Estado". ${ }^{19}$

Diz o artigo sexto da vigente Constituição: "São direitos sociais a educação, a saúde, o trabalho, a moradia, o lazer, a segurança, a previdência social, a proteção à maternidade e à infância, a assistência aos desamparados, na forma desta constituição". Neste texto constitucional é possível entender que o legislador constituinte transferiu ao legislador ordinário a competência para regular tais direitos. Assim, em resumo, "os direitos sociais, nas hipóteses em que não são prontamente desfrutáveis, dependem, em geral, de prestações positivas do Poder Executivo ou de providências normativas do Poder Legislativo". ${ }^{20}$

Apesar de restrita sua aplicação, a importância deste artigo encontra-se no fato de que o mesmo estabelece "autênticos direitos subjetivos inerentes ao espaço existencial do cidadão, independentemente da sua justicialidade e exequibilidade imediata". ${ }^{21}$

Em face do exposto, entende-se que o direito à educação possui natureza jurídica de direito fundamental, plenamente exigível, porém, aplicável com o auxilio de alguns dispositivos constitucionais e também infraconstitucionais.

Importante lembrar o que diz Regina Maria Fonseca Muniz:

O direito à educação é mais que um direito social de segunda dimensão: é um direito fundamental de primeira grandeza e da personalidade, inserido no direito à vida no seu sentido integral, isto é, como meio necessário a uma perfeita e solida formação do homem e pelo papel decisivo que ele exerce na preservação da coesão social. ${ }^{22}$

\footnotetext{
${ }^{18}$ SILVA, José Afonso da. Curso de direito constitucional positivo. 24. ed. São Paulo: Malheiros, 2004. p.286.

${ }^{19}$ SARLET, Ingo Wolfgang. A eficácia dos direitos fundamentais. Porto Alegre: Livraria do Advogado, 1998. p.29.

${ }^{20}$ BARROSO, Luis Roberto. O direito constitucional e a efetividade de suas normas. 6 . ed. Rio de Janeiro: Renovar, 2002 .p. 112.

${ }^{21}$ CANOTILHO, J.J Gomes. Direito Constitucional e teoria da constituição. 3. ed. Coimbra - Portugal: Almedina, 1997. p.446.

${ }^{22}$ MUNIZ, Regina Maria Fonseca. O direito à educação. Rio de Janeiro: Renovar, 2002. p.122.
} 


\section{O cumprimento das normas constitucionais: $O$ conflito entre o Legislativo, Executivo e o Judiciário na efetivação do direito à educação}

Um dos maiores desafios impostos à Constituição Federal brasileira é sem dúvida a efetividade de suas normas, sobretudo, aquelas que tratam da defesa dos direitos sociais, cuja natureza foi, por alguns, reconhecida como expectativa e não como direito subjetivo. ${ }^{23}$ Isso ocorre pelo fato de serem tais normas classificadas como programáticas, tema este, cercado de grande problemática até os dias atuais.

Diz Regina Maria Macedo Nery que "essas normas são, verdadeiramente, o grande problema a enfrentar quando se quer analisar a aplicabilidade das normas constitucionais e, principalmente, a justiciabilidade das normas programáticas." 24

Norberto Bobbio questionou em sua obra Era dos Direitos, sobre a efetiva aplicação das normas constitucionais chamadas programáticas. Este autor defendeu que há uma enorme defasagem entre a posição da norma e sua efetiva aplicação, pois tais normas "proíbem ou permitem em um futuro indefinido e sem prazo de carência claramente delimitado" ${ }^{25}$. Fato esse, gerador de enorme insegurança aos que aguardam para desfrutar de tais direitos que lhes são essenciais.

Entretanto, não se pode olvidar o fato de que tantos outros, como Eros Roberto Grau, já reconhecem as normas programáticas, sobretudo as atributivas de direitos sociais e econômicos como "diretamente aplicáveis e imediatamente vinculantes do Legislativo, Executivo e Judiciário" ${ }^{26}$. Ou seja, independem de norma posterior que as regulem, pois, o simples fato de estarem apontadas pela Constituição já vincula os Poderes estatais ao seu cumprimento.

Apesar das idéias apontadas acima, Eros Grau compactua, em um segundo momento, com as angústias de Bobbio. Ele defende que as normas programáticas possuem um caráter reacionário, pois:

\footnotetext{
${ }^{23}$ MIRANDA, Jorge. Manual de direito constitucional. Coimbra - Portugal: Editora Coimbra, 1991.t.II. p.244/245. ${ }^{24}$ NERY, Regina Maria Macedo. Normas constitucionais programáticas. São Paulo: Revista dos Tribunais, 1994.p. 108. Apud. PIOVESAN, Flávia. Proteção judicial contra omissões legislativas. 2.ed. São Paulo: Revista dos Tribunais, 2003.p.71.

${ }^{25}$ BOBBIO, Norberto. Era dos direitos, trad. Carlos Nelson Coutinho. Rio de Janeiro: Campus, 1992.p.77-78.

${ }^{26}$ GRAU, Eros. A constituição brasileira e as normas programáticas. Revista de Direito Constitucional e Ciência Política. Rio de Janeiro: Forense.n.4.p.42-43.
} 


\begin{abstract}
Nelas se erige não apenas um obstáculo à funcionalidade do direito mas, sobretudo ao poder de reivindicação das forças sociais. O que teria a sociedade civil a reivindicar já está contemplado na Constituição. Não se dando conta, no entanto, da inocuidade da contemplação desses direitos sem garantias, a sociedade civil acomoda-se, alentada e entorpecida pela perspectiva de que esses mesmos direitos um dia venham a ser realizados. ${ }^{27}$
\end{abstract}

Situação perigosa ao Estado Democrático de Direito uma vez que se a sociedade não se manifesta o poder público poderá permanecer inerte, mesmo em face da existência de norma constitucional que vincule seu dever de tutelar os direitos fundamentais garantidos à população. Daí a importância dos três poderes trabalharem juntos na efetivação das normas constitucionais, especialmente, as programáticas.

A fiscalização recíproca entre os poderes traria mais eficiência ao cumprimento deste desafio, pois, se o legislador não der subsídios ao cumprimento de um direito, poderá o Judiciário alertá-lo, ou até mesmo o Executivo poderá pleitear amparo da lei para garantir à sociedade a execução dos direitos que lhes são essenciais.

Alerta Flávia Piovesan que "a programaticidade sem juridicidade poderá, enfim, converter-se formal e materialmente no maior obstáculo à construção constitucional de um verdadeiro Estado de Direito" ${ }^{28}$. É por esse motivo que a tese defendida por parte da doutrina, de que as normas programáticas estão submetidas à discricionariedade do legislador, e assim não consentem que a sociedade invoque por si só seu cumprimento ao judiciário, deve ser analisada cuidadosamente. Pois, deste entendimento presume-se que as normas programáticas não traduzem verdadeiros direitos subjetivos, mas sim "meras expectativas de direitos subjetivos" 29.

Por esse motivo, é que não se pode olvidar que os direitos sociais, em especial o direito à educação, já estão dotados de normatividade vinculante pelo simples fato de estarem incorporados ao texto constitucional. Assim, independentemente de serem ditas programáticas tais normas não podem ser simplesmente promessas políticas, mas sim Direitos efetivados.

A avaliação critica desta problemática leva a uma questão: Diante da inércia do legislador, o cidadão não poderá gozar dos direitos que lhes são garantidos constitucionalmente?

\footnotetext{
${ }^{27}$ GRAU, Eros. A constituição brasileira e as normas programáticas. Revista de Direito Constitucional e Ciência Política. Rio de Janeiro: Forense.n.4.p.42-43.

${ }^{28}$ PIOVESAN, Flávia. Proteção judicial contra omissões legislativas. 2.ed. São Paulo:Revista dos Tribunais, 2003.p.73.

${ }^{29}$ PIOVESAN, Flávia. Proteção judicial contra omissões legislativas. 2.ed. São Paulo: Revista dos Tribunais, 2003.p.76.
} 
Para José Afonso da Silva a omissão do legislador poderá ser considerada inconstitucional por força do artigo 103, parágrafo $2^{\circ}$ da Constituição de 1988. Diz o jurista que "tendo a Constituição reconhecido a inconstitucionalidade por omissão, a obrigação de legislar, especialmente após o reconhecimento jurisdicional dessa inconstitucionalidade, tem natureza jurídica e moral" ${ }^{30}$. Destarte, o cidadão que não tem acesso a qualquer direito subjetivo que lhe assiste, por inércia do legislador, pode recorrer ao judiciário para alcançar a concretização deste direito.

Partindo do entendimento que o judiciário pode, e deve, agir na efetivação dos direitos constitucionalmente tutelados, a juridicidade ${ }^{31}$ das normas constitucionais pode ser destacada em dois níveis distintos. O primeiro é o que vincula o legislativo à decisão do judiciário. O segundo é o que vincula o Executivo às decisões judiciais.

No primeiro nível acima apontado, destaca-se a possibilidade de o judiciário agir, amparado pela constituição, quando houver inércia do legislador no que diz respeito à regulamentação dos comandos constitucionais no que tange o direito à educação.

É certo que o legislador infraconstitucional regulamentou parte das normas constitucionais que tratam do direito à educação, como prova, nota-se a Lei de Diretrizes e Bases da Educação (Lei nº 9394/96), o PNE (Plano Nacional da Educação) e o Fundeb.

Entretanto, questiona-se se estes comandos infraconstitucionais foram suficientes para que o direito à educação fosse aplicado exatamente como requer a constituição brasileira de 1988. A reposta para tal questionamento é simples, basta analisar o ensino público nos estados brasileiros e concluir que mesmo com a regulamentação do legislador as discrepâncias entre efetivação do direito à educação e normas constitucionais são grandes.

Nota-se, portanto, o que a doutrina chama de omissão inconstitucional parcial, que se caracteriza, resumidamente, pela existência de normas regulamentadoras que não satisfazem as exigências constitucionais, ou seja, mesmo diante da ação do legislador ordinário, as normas constitucionais continuam sem eficácia.

\footnotetext{
${ }^{30}$ SILVA, José Afonso da. Aplicabilidade das normas constitucionais. 3.ed. São Paulo: Malheiros, 1999.p.129.

${ }^{31}$ A juridicidade indica neste ponto a possibilidade de se tutelar questões constitucionais em juízo, ou seja, a oportunidade de que tais questões sejam discutidas e que possam ser aplicadas nas relações sociais por meio da ação de quem é responsável por sua concretização.
} 
A grande angústia estava na possibilidade de o judiciário possuir ou não legitimidade para complementar as omissões parciais do legislador e suprir a falta da ação do mesmo, na chamada inconstitucionalidade por omissão total.

Entretanto, tal sentimento foi acalmado pela Constituição Federal de 1988, que criou mecanismos de controle da constitucionalidade, como a ação direta de inconstitucionalidade por omissão e o mandado de injunção ${ }^{32}$, as quais garantem ao judiciário agir na inércia do legislador sem que se fale em quebra de limites da atuação de cada um desses poderes.

Assim, ao incluir em seu texto essas duas medidas, a constituição buscou "conferir aplicabilidade imediata a seus preceitos, principalmente aos definidores de direitos e garantias fundamentais, não sendo mais admissível exigir-se do destinatário da norma que aguarde em espera indefinida, a confecção das normas regulamentadoras faltantes". ${ }^{33}$

Portanto, o judiciário possui respaldo constitucional quando for necessária sua intervenção para que se cumpra o direito à educação, perante a não atuação, ou atuação defeituosa do legislador infraconstitucional, no que diz respeito ao cumprimento deste direito. E é certo que nos dias atuais torna-se imprescindível a atuação do judiciário neste sentido, pois, a intenção não é usurpar do poder legislativo, mas sim, socorrer a uma necessidade social.

Mas, é importante lembrar, e a doutrinadora Cristina Queiroz chama atenção para este fato, que "a responsabilidade pela concretização e especificação desses direitos compete, em primeira linha, ao legislador", pois, não é possível e aceitável "aos tribunais gerir uma política econômica e social - domínio específico do poder legislativo". 34

Por esse motivo, é que as decisões do judiciário nas chamadas ações direitas de inconstitucionalidade, bem como, nos mandados de injunção dão aplicabilidade aos direitos por elas defendidos, entretanto, não obrigam o legislador a regulamentar a questão. Assim, tanto as decisões do controle difuso quanto do controle concentrado ${ }^{35}$ embora estabeleçam situações que

\footnotetext{
${ }^{32}$ Tais medidas mencionadas serão analisadas de forma mais ampla nos próximos parágrafos.

${ }^{33}$ PIOVESAN, Flávia. Proteção judicial contra omissões legislativas. 2.ed. São Paulo: Revista dos Tribunais, 2003.p.109.

${ }^{34}$ QUEIROZ, Cristina. Direitos fundamentais sociais: questões interpretativas e limites de justiciabilidade. In: SILVA, Virgilio Afonso da (org.). Interpretação Constitucional. São Paulo: Malheiros, 2005.p.189.

${ }^{35}$ Chama-se controle difuso de constitucionalidade, aquele que poderá ser exercido por qualquer magistrado no julgamento de situações concretas que se mostram como incompatíveis à Constituição Federal. Já o controle concentrado de constitucionalidade tratará de matérias abstratas, levadas ao conhecimento do STF somente pelos legitimados pelo artigo 103 da Constituição Federal, na intenção de que a Suprema Corte se manifeste pela constitucionalidade ou inconstitucionalidade da norma em questão.
} 
devam ser efetivados pelo poder público, poderão ser julgadas inúmeras vezes caso o legislador não proceda à regulamentação da matéria já discutida em juízo.

Explica-se, portanto, quando José Afonso da Silva diz que o cumprimento desta determinação do judiciário pelo legislativo tem caráter moral $^{36}$, pois, a própria Constituição não vincula o legislador a regulamentar aquilo que decidiu os tribunais, cabendo somente ao poder legislador agir ou não ${ }^{37}$.

Explica-se, também, a grande quantidade de súmulas que são editadas a fim de que matéria que já foi decidida não precise ser novamente apreciada, visto que, o direito já foi discutido, e o legislador permaneceu inerte. Esse fenômeno, apenas em nível de curiosidade, acaba gerando grandes discussões doutrinarias, já que muitos acreditam que a edição de súmulas, principalmente as vinculantes, são formas de o judiciário também legislar.

Enfim, no que diz respeito ao direito à educação, o que se aplica também a outros direitos fundamentais, uma decisão judicial que determina algo no caso concreto, até mesmo em abstrato, não obrigará o Legislativo, fato este que demonstra a importância do judiciário como guardião dos direitos fundamentais. Pois, mesmo que o legislador não aja, o titular do direito terá sua pretensão apreciada e quiçá efetivada, já que a efetivação dependerá de outros fatores que serão, abaixo, analisados.

Como salienta Sérgio Fernando Moro, "o dogma da vedação da atuação do juiz como legislador positivo não se sustenta quando presente violação da constituição" ${ }^{38} \mathrm{e}$ ainda, defende que "o juiz tem, frente a casos concretos, o dever legal de dizer o direito aplicável, mesmo que para isso seja necessário invalidar ato legislativo inconstitucional ou suprir omissão legislativa inconstitucional" 39 .

Mas, e quanto ao cumprimento das decisões judiciais pelo Executivo? Como agirá esse poder em face de determinação judicial para que se cumpra um direito que antes não havia sido regulado pelo legislador, mas que subitamente tornou-se de cumprimento imediato?

\footnotetext{
${ }^{36}$ SILVA, José Afonso da. Aplicabilidade das normas constitucionais. 3.ed. São Paulo: Malheiros, 1999.p.129.

${ }^{37}$ Mas, vale lembrar que, como já foi discutido por este trabalho, o legislador possui a obrigação de dar eficácia à norma constitucional de caráter programático, portanto, ele não está obrigado a legislar mediante decisão judicial, mas está obrigado constitucionalmente a dar aplicabilidade à preceitos constitucionais que, teoricamente, dependem de sua ação para possuírem eficácia.

${ }^{38}$ MORO, Sérgio Fernando. Desenvolvimento e efetivação judicial das normas constitucionais. São Paulo: Max Limonad, 2001.p.124.

${ }^{39}$ MORO, Sérgio Fernando. Desenvolvimento e efetivação judicial das normas constitucionais. São Paulo: Max Limonad, 2001.p.85.
} 
Entre tantas incertezas trazidas por essa questão, está principalmente a disponibilidade de recursos e ainda, a discussão de até que ponto o Executivo deve realizar uma determinação judicial, que, por exemplo, o obriga a abrir mais vagas em uma escola pública, mesmo não possuindo recursos para tanto.

Neste momento a discussão passa para o campo da concretização e operacionalização de tal direito fundamental, que requererá dispêndio de recursos e atuação da administração para sua efetivação. Assim, é preciso considerar que em matéria de diretos econômicos, culturais e sociais (aqui se engloba a educação), pode-se argumentar, com alguma razão, que "tais direitos pressupõem uma ponderação em face de outros bens e princípios constitucionais designadamente, o princípio do equilíbrio financeiro e orçamental, ou mesmo a chamada reserva do possivel." 40

Por outro lado, não há dúvidas de que o Estado possua o dever de cumprir decisão judicial que determine a realização de um direito fundamental, mais ainda, independentemente de qualquer decisão judicial é seu dever prestar à sociedade os direitos que lhes são garantidos constitucionalmente. Já que, ao administrador se impõe deveres positivos e negativos para que este observe os limites e promova os fins da Constituição ${ }^{41}$.

Destarte, mesmo com a falta de recursos é obrigação do Estado proceder a garantia de um mínimo social, ou seja, um mínimo existencial para que a realização do direito fundamental se concretize. Esse mínimo mencionado não é de fácil delimitação. O que seria, para o direto à educação, a realização por parte do Estado deste mínimo social?

A doutrina alemã entende que tal mínimo deve estar conforme a essência ou ao conteúdo dos direitos fundamentais ${ }^{42}$. Neste sentido, cabe ao Estado realizar as pretensões estabelecidas pela Constituição, atendendo seu conteúdo essencial.

Por exemplo, para a garantia do direito à educação, dentro da essência constitucional, o Estado deve no mínimo garantir vagas nas escolas para todos os titulares deste direito, ainda,

\footnotetext{
${ }^{40}$ QUEIROZ, Cristina. Direitos fundamentais sociais: questões interpretativas e limites de justiciabilidade. In: SILVA, Virgilio Afonso da (org.). Interpretação Constitucional. São Paulo: Malheiros, 2005.p.175.

${ }^{41}$ Luis Roberto BARROSO entende que a partir do movimento de constitucionalização dos ramos do direito, em especial do Direito Administrativo, o administrador passou a ter legitimidade para agir não mais se baseando somente no princípio da legalidade, mas sim, "deve atuar tendo por fundamento direto a Constituição e independentemente, em muitos casos, de qualquer manifestação do legislador ordinário". BARROSO, Luis Roberto. Neoconstitucionalismo e constitucionalização do direito (o triunfo tardio do direito constitucional no Brasil). In: Revista brasileira de direto público - RBDP. n ${ }^{\circ}$ 11, out/dez, 2005. Editora Fórum. p. 54.

${ }^{42}$ QUEIROZ, Cristina. Direitos fundamentais sociais: questões interpretativas e limites de justiciabilidade. In: SILVA, Virgilio Afonso da (org.). Interpretação Constitucional. São Paulo: Malheiros, 2005.p.181.
} 
deverá disponibilizar bons profissionais que ministrem as aulas voltados para o desenvolvimento intelectual e moral dos alunos. Este seria o mínimo no que diz respeito à educação. Nota-se, porém, que em muitos casos se quer o mínimo é realizado.

Assim, a falta de recursos não deve ser justificativa para a administração se omitir do cumprimento das prestações sociais. A mesma deverá ponderar seus gastos com as necessidades diversas da sociedade, que podem surgir de maneira inesperada, principalmente, quando se fala de cumprimento de direitos fundamentais. Agir com base na proporcionalidade não poderá ser uma desculpa da administração para não cumprir com sua obrigação de prestação.

A própria Constituição Federal apresenta medida que poderá ser utilizada contra a inércia do poder público na realização de prestações. É a conhecida declaração de inconstitucionalidade por omissão, que neste caso será notada quando não forem praticados atos administrativos requeridos para tornar plenamente aplicáveis normas constitucionais (art. 103, parágrafo $2^{\circ}$, da Constituição Federal).

Como explica José Afonso da Silva, muitas normas constitucionais dependem de uma providência administrativa ulterior, a fim de que os direitos por elas traçados se efetivem na prática. "Se esses direitos não se realizam porque o administrador não criou o ato, dá-se uma omissão inconstitucional, surgindo daí o pressuposto para a propositura de uma ação de inconstitucionalidade por omissão (...) visando a obter a prática do ato". ${ }^{4}$

Por exemplo, cita-se a educação que é um direito de todos e dever do Estado. Se o poder público não produz atos administrativos indispensáveis para que se realize tal direito em benefício dos interessados estará configurada uma omissão constitucional da administração, que possibilitará a interposição da ação direta de inconstitucionalidade por omissão.

A decisão do órgão judiciário competente (STF), que julgar essa inconstitucionalidade, vinculará os demais órgãos do Poder Judiciário e principalmente, os órgãos da administração direita e indireta, nas esferas federal, estadual e municipal (art.102, parágrafo $2^{\circ}$ da Constituição Federal). Portanto, a decisão do judiciário, no tocante à realização/efetivação de direitos constitucionais pelo órgão administrativo, gera para este a obrigação de tomar providências para sua realização, cujo prazo estabelecido pela Constituição para seu cumprimento é de trinta dias $\left(103\right.$, parágrafo $\left.2^{\circ}\right)$.

\footnotetext{
${ }^{43}$ SILVA, José Afonso da. Comentário contextual à constituição.3.ed. São Paulo: Malheiros, 2007.p.558.
} 
Percebe-se, portanto, que ao contrário do que ocorre com o Poder Legislativo, a própria Constituição obriga o Poder Executivo a cumprir decisão judicial que fixa a realização de direitos constitucionais positivados. Isso acontece, pois, como já anteriormente mencionado, o que está em jogo é um direito intrínseco à dignidade e personalidade de seu titular, que não poderá ser prejudicado em face do descaso do Legislativo, bem como do Executivo, em um primeiro momento.

Caso não seja possível a utilização da ADIN para sanar omissões da administração, nos termos do artigo 102, parágrafo $1^{\circ}$ da Constituição, caberá a Argüição de Descumprimento de Preceito Fundamental, que possui alguns requisitos a serem seguidos (Lei nº. 9882/99), no entanto, tem como principal intenção a tutela da lesão a preceito constitucional fundamental, por exemplo, o direito à educação. Assim, qualquer ato do Poder Público que contrariar tais preceitos, nos termos da lei supracitada, ensejará a aplicação de tal medida, não havendo outra cabível. $^{44}$

Finalmente, fala-se, também, em ação direta de inconstitucionalidade interventiva. Esta está estipulada no artigo 34, VII da Constituição, que diz que não haverá intervenção da União nos Estados e Municípios, exceto quando não ocorrer a aplicação do mínimo exigido da receita resultante de impostos, na manutenção e desenvolvimento do ensino e saúde. Esta ação será proposta junto ao STF, que a julgará. Se procedente o Presidente decreta a intervenção, a fim de que a irregularidade seja sanada. O titular do direito de Ação, neste caso, é o Procurador Geral da República (art.36, III da Constituição Federal).

Extrai-se do exposto, a vinculação do poder executivo às decisões judiciais, especialmente às do STF. Neste instante a preocupação será quais devem ser os limites desta vinculação, se é que se pode falar em limites, e quais são as alternativas do poder público para a prestação de um direito fundamental como a educação.

\section{A reserva do possível e a justiciabilidade do direito à educação}

A tensão central deste estudo tem lugar na obrigação do poder público em concretizar e operacionalizar o direito à educação à sociedade. Assim, o legislador em alguns casos, oferece ao Executivo as diretrizes a serem seguidas para a realização de tal direito, como por exemplo,

\footnotetext{
${ }^{44}$ Um dos principais diferenciais da ADPF é de que esta poderá ser requerida para promover a discussão, também, de ato normativo municipal e não somente federal e estadual como é o caso da ADIN julgada pelo STF.
} 
quando estabelece qual porcentagem orçamentária deve ser destinada à manutenção da educação dentro de um exercício financeiro. Mas, em outros momentos o legislador permanece inerte, não criando meios de efetivação de tal direito, ou ainda, a própria administração furta da sociedade o cumprimento do direito à educação como manda a Lei Maior.

Nestes dois últimos momentos, é que se questiona a justiciabilidade deste direito fundamental. Por justiciabilidade entende-se a possibilidade de reclamar perante um juiz ou tribunal a realização das obrigações que derivam de um direito. Os direitos sociais, aqui se inclui a educação, "são direitos constitucionalmente garantidos, não simples aspirações ou proclamações políticas" ${ }^{45}$. Destarte, "independentemente da questão de sua qualificação como direito subjetivo, haverá que indagar previamente se sua invocação permitirá predicar a correspondente ação em juízo" 46 .

Assim, independentemente de sua subjetividade, não deixa de ser certo afirmar que: "na ausência de instrumentos legislativos de densificação e concretização, deste direito, tendencialmente caberá aos tribunais, e particularmente aos tribunais de justiça constitucional, a tarefa de respeitar a constituição através do controle jurisdicional" ${ }^{47}$, como lembrado por Cristina Queiroz.

É possível defender, portanto, que o direito à educação é dotado de justiciabilidade, pois, sua concretização poderá ser buscada por intermédio de decisão judicial. Mas, qual será o limite desta justiciabilidade?

Esta é uma questão complexa para qual não se vislumbra uma resposta unívoca. Quando o Judiciário fixa, hipoteticamente, que as escolas de ensino fundamental deverão oferecer cursos de aperfeiçoamento a seus professores, a fim de melhor prepará-los e na intenção de que os alunos tenham acesso a um ensino de melhor qualidade, sua pretensão é adequar a prestação do direito à educação como manda a Constituição.

Fica neste momento clara a "tentativa" de intervenção do judiciário nos planos do Executivo. Mas, ao mesmo passo que tal intervenção se justifica, pelos motivos já acima expostos, tem-se por outro lado o entendimento de que é ao legislador que compete, "dentro das reservas

\footnotetext{
${ }^{45}$ QUEIROZ, Cristina. Direitos fundamentais sociais: questões interpretativas e limites de justiciabilidade. In: SILVA, Virgilio Afonso da (org.). Interpretação Constitucional. São Paulo: Malheiros, 2005.p.194.

${ }^{46}$ QUEIROZ, Cristina. Direitos fundamentais sociais: questões interpretativas e limites de justiciabilidade. In: SILVA, Virgilio Afonso da (org.). Interpretação Constitucional. São Paulo: Malheiros, 2005.p.194.

${ }^{47}$ QUEIROZ, Cristina. Direitos fundamentais sociais: questões interpretativas e limites de justiciabilidade. In: SILVA, Virgilio Afonso da (org.). Interpretação Constitucional. São Paulo: Malheiros, 2005.p.195.
} 
orçamentais, dos planos econômicos e financeiros, das condições sociais e econômicas do país, garantir as prestações integradoras dos direitos sociais (...)" ${ }^{48}$.

Destarte, busca-se com a ação do legislador a objetivação de um direito que tem caráter extremamente subjetivo, mas que em nenhum momento pode ter sua justiciabilidade desconsiderada. Diz Cristina Queiroz que "nos casos de direitos de natureza econômica, cultural e social essa justiciabilidade encontra-se dependente de uma configuração jurídica particular a levar a cabo pelo legislador" 49 .

Entende-se, destas disposições, que pouco se pode fazer no que diz respeito aos direitos de prestações quanto à sua imputabilidade ao Executivo quando não houver lei infraconstitucional que o regulamente. Mas, quando o Judiciário estiver determinando o cumprimento, pelo Executivo, de direito constitucional já legislado infraconstitucionalmente, esse não poderá se esquivar de seu cumprimento.

No caso hipotético acima citado, se houver regulamentação em norma infraconstitucional da necessidade de se oferecer cursos de aperfeiçoamento ao corpo docente das escolas de ensino fundamental, esta norma deverá ser obrigatoriamente prestada pelo poder público, e caso não seja, caberá, sem dúvidas, ação do judiciário contra essa omissão.

Ainda, neste caso hipotético, questiona-se o que poderá ser feito se o legislador não regulamentar esta pretensão jurisdicional garantidora de direito constitucionalmente tutelado? $\mathrm{O}$ titular do direito deverá se conformar com seu não cumprimento?

Além do que já foi discutido anteriormente, como reposta há o princípio da aplicabilidade imediata das normas definidoras de direitos e garantias fundamentais. Cujos efeitos são bem expostos por Flavia Piovesan:

Com efeito, a partir do princípio da aplicabilidade imediata das normas definidoras de direitos e garantias fundamentais, toda e qualquer norma definidora de direitos e garantias fundamentais há de alcançar aplicação imediata e, neste sentido devem orientar os poderes públicos. Vale dizer, cabe aos Poderes Públicos conferir eficácia máxima e imediata a todo e qualquer preceito constitucional definidor de direito e garantia fundamental. ${ }^{50}$

\footnotetext{
${ }^{48}$ CANOTILHO, José Joaquim Gomes Canotilho. Constituição dirigente e vinculação do legislador. 2. ed. Coimbra - Portugal: Coimbra Editora, 2001.p.369.

${ }^{49}$ QUEIROZ, Cristina. Direitos fundamentais sociais: questões interpretativas e limites de justiciabilidade. In: SILVA, Virgilio Afonso da (org.). Interpretação Constitucional. São Paulo: Malheiros, 2005.p.211.

${ }^{50}$ PIOVESAN, Flávia. Proteção judicial contra omissões legislativas. 2.ed. São Paulo: Revista dos Tribunais, 2003.p.105.
} 
Desta maneira, caso o titular do direito à educação fosse obrigado a aguardar a confecção de norma infraconstitucional para ter acesso ao mesmo, "configurar-se-ia verdadeira subversão da ordem jurídica, apresentando-se a omissão do legislador infraconstitucional mais eficaz à atuação do constituinte, a inexistência de norma regulamentadora mais vinculante que a existência de norma constitucional." 51

Assim, não parece razoável que um direito constitucional pudesse ser suprimido de seus titulares pela inércia do legislador. Neste sentido, aos órgãos judiciais compete:

a) interpretar os preceitos constitucionais consagradores de direitos fundamentais, na sua aplicação em casos concretos, de acordo com o princípio da efetividade ótima ${ }^{52}$; b) densificar os preceitos constitucionais consagradores de direitos fundamentais de forma a possibilitar a sua aplicação imediata, nos casos de ausência de leis concretizadoras. ${ }^{53}$

Em face deste entendimento, quando houver a ação do judiciário impondo à administração pública a efetivação do direito à educação ${ }^{54}$, estando a situação concreta prevista ou não em lei infraconstitucional, o direito deverá ser prestado de acordo com o princípio da proporcionalidade e da reserva do possível.

A reserva do possível é vista como aquilo que o indivíduo pode razoavelmente exigir da sociedade e que lhe será dado com certa ponderabilidade. Isto, pois, assim como há inúmeras necessidades a serem supridas pelo executivo no âmbito do direito à educação, também se notam necessidades quanto à realização de outros direitos sociais, como a saúde, a segurança, entre outros.

\footnotetext{
${ }^{51}$ PIOVESAN, Flávia. Proteção judicial contra omissões legislativas. 2.ed. São Paulo: Revista dos Tribunais, 2003.p.109.

${ }^{52}$ Efetividade ótima nada mais é do que a interpretação das normas legais conforme a realização efetiva dos direitos sociais, econômicos e culturais. Cf. QUEIROZ, Cristina. Direitos fundamentais sociais: questões interpretativas e limites de justiciabilidade. In: SILVA, Virgilio Afonso da (org.). Interpretação Constitucional. São Paulo: Malheiros, 2005.p.198.

${ }^{53}$ PIOVESAN, Flávia. Proteção judicial contra omissões legislativas. 2. ed. São Paulo: Revista dos Tribunais, 2003.p.107.

${ }^{54}$ É bom lembrar que quando se fala em ação do judiciário deve-se entender que no que diz respeito a casos concretos essa ação deverá ser pleiteada por aqueles que se sintam lesados. Assim, um indivíduo poderá pleitear a efetivação de determinado direito constitucional acionando o judiciário que realizará nestes casos o controle difuso de constitucionalidade. Mas, quando a questão mostrar-se de maneira abstrata e ainda, atingir uma coletividade a questão sobre o controle de constitucionalidade deverá ser levado ao STF por meio da ADIN, apenas pelos legitimados no artigo 103 da Constituição de 1988.
} 
Portanto, o judiciário poderá estabelecer ao Executivo que o mesmo disponibilize, por exemplo, mais vagas no ensino fundamental em uma determinada região, a fim de atender as necessidades sociais do local. Entretanto, o Judiciário não poderá interferir na quantidade de recursos que o poder público disponibilizará para cumprir esta estipulação, já que esta é uma questão política que diz respeito à administração, a qual possui como uma de suas tarefas principais, a função de organizar e distribuir recursos de modo a atender as necessidades sociais.

Nesses termos, é que a decisão do judiciário deverá estar pautada nos limites daquilo que é razoável. Assim, o atendimento pelo Estado do direito à educação demanda recursos e tudo aquilo que demanda dinheiro não pode ser absoluto, e é aqui que o Judiciário deverá estar atento, pois, "nenhum direito cuja eficácia pressupõe o gasto seletivo dos recursos dos contribuintes pode, em última instância, ser protegido unilateralmente pelo Judiciário, sem a observância das consequiências orçamentárias que afetam a competência dos outros poderes". 55

Não é razoável que o poder público tenha que tirar recursos da saúde, por exemplo, para suprir as necessidades da educação. Por outra banda, não é justo que o ensino não se efetive por causa de recursos. E é perante essas situações de ilimitadas necessidades dos indivíduos e carência de recursos que o Poder Público muitas vezes deve fazer escolhas dramáticas.

Caberá ao interprete constitucional, portanto, dosar a maior ou menor necessidade de atendimento de determinado direito fundamental em suas decisões, pautando-se nos princípios da proporcionalidade e razoabilidade na busca de que os recursos sejam aplicados com mais justiça e sem desperdícios.

Mas, é valido deixar claro que o Judiciário poderá opinar nesses casos difíceis de aplicação de recursos, especialmente se forem flagradas desproporcionalidades quanto sua utilização. Entretanto, as escolhas de alocação de recursos devem ficar "por conta dos órgãos políticos competentes para fixar as linhas mestras da política financeira e social" ${ }^{56}$. Espera-se, neste sentido, que os governantes optem pela melhor forma de empregar os recursos públicos, buscando, principalmente, a redução das desigualdades sociais.

\footnotetext{
${ }^{55}$ HOLMES, Stephen \& Sustein, Cass R. The cost of rights: why liberty depends on taxes. New York: W.W. Norton \& Co.,1999.p. 97. Apud AMARAL, Gustavo. Direito, escassez e escolha. Rio de Janeiro: Renovar, 2001. p. $103-231$. ${ }^{56}$ BRAGA, Valeschka e Silva. Princípios da proporcionalidade e da razoabilidade. Curitiba: Juruá Editora, 2004. p. 150.
} 
Assim, o Judiciário poderá agir no que diz respeito à efetivação do direito à educação, mas o Poder Público poderá efetivar tal determinação dentro de um limite possível, interpretando a ordem judicial e considerando os demais direitos sociais, já que as necessidades são ilimitadas.

Como destaca Böckenförde:

A concreta garantia do direito fundamental depende dos meios estatais disponíveis. A impossibilidade econômica se apresenta como limite - necessário- da garantia (prestação) dos direitos fundamentais (...). As inevitáveis decisões sobre prioridades, sobre emprego e distribuição dos meios financeiros estatais disponíveis, motivados pela escassez de recursos, passam a ser, de uma questão de discricionariedade política a uma questão de observância dos direitos fundamentais; com isto, se convertem, formalmente, em uma questão de interpretação dos direitos fundamentais ${ }^{57}$.

\section{Maneiras de realização do ensino: o papel do Judiciário perante o direito à educação}

A legislação disponibiliza, aos titulares do direto à educação, diversas alternativas destinadas à garantia de seus direitos, na verdade elas são meios processuais de proteção dos direitos dos cidadãos. Como apreciador destes meios processuais está o Poder Judiciário. Lembra bem Luis Roberto Barroso que a função deste órgão, é "prestar a jurisdição, que é atividade estatal destinada a fazer atuar o direito objetivo, promovendo a tutela dos interesses violados ou ameaçados". 58

O próprio direito educacional pode ser entendido como um "instrumento capaz de levar a educação a todos. Isto é, sair do enunciado e da declaração que 'todos tem direito à educação', para a efetivação individual e social, administrativa e judiciária da educação" 59 .

Assim, dispõe Elias de Oliveira Motta:

\footnotetext{
${ }^{57}$ No original: "La concreta garantia de derecho fundamental deviene dependiente de los médios finacilros estatales disponibles. La impossibilidad economica se presienta como limite - necessário - de la garantia( prestacion) de los derechos fundamentales (...). Las inevitables deicisiones sobre prioridades, sobre el exempleo y distribuicion de los médios financieros estatales disponibles, motivados por la escassez de recursos, passan de uma cuestión de discricionalidad política a uma cuestión de observancia de los derechos fundamentales, más exactamente: de concurrencia y conflicto de derechos fundamentales; com ello se convierten, formalmente, em uma cuestión de interpretación de los derechos fundamentales". BÖCKENFÖRDE, Ernest -Wolfgang. Teória e interpretación de los derechos fundamentales. In: Escritos sobre derechos fundamentales. Baden - Baden: Nomos, 1993. p. 44-45, apud AMARAL, Gustavo. Interpretação dos direitos fundamentais e o conflito entre os poderes. In: TORRES, Ricardo Lobo (Org). Teoria dos direitos fundamentais. Rio de Janeiro: Renovar, 1999. p. 103-104.

${ }^{58}$ BARROSO, Luis Roberto. O direito constitucional e a efetividade de suas normas. 6.ed. Rio de Janeiro: Renovar, 2002.p.125.

${ }^{59}$ MOTTA, Elias de Oliveira. Direito educacional e educação no século XXI: incluindo comentários à nova lei de diretrizes e bases da educação nacional e legislação conexa e complementar. Brasília: UNESCO, 1997.p.228.
} 
O $\S 2^{\circ}$ do artigo 208 da Constituição, determina que, nos casos de não oferecimento do ensino fundamental, se comprovada a negligencia da autoridade competente para garantir oferecimento do ensino obrigatório, poderá essa autoridade ser imputada por crime de responsabilidade. Esta ordem da lei poderá levar administradores municipais e estaduais relapsos em relação à destinação dos recursos para a manutenção e desenvolvimento do ensino em suas áreas de competência a terem uma maior atenção para com a questão educacional. A previsão de punibilidade para os negligenciadores, por si só, já é um grande avanço e demonstra a preocupação de nossos parlamentares em tornar efetivo o direito à educação. ${ }^{60}$

Qualquer pessoa que se sinta lesada pela omissão da prestação da educação poderá se utilizar deste instrumento que é a imputação de crime de responsabilidade.

Além desta, há outras formas para que o cidadão defenda seu direito à educação, entre elas, as medidas constitucionais do Mandado de Injunção (art. $5^{\circ}$, LXXI), da Inconstitucionalidade por Omissão (art.103, parágrafo $2^{\circ}$ ) e da Iniciativa Popular (art.61, parágrafo $2^{\circ}$ ). Nestes casos o cidadão buscará defender seu direito face à omissão do legislador que deixou de regulamentá-lo, ou em face de sua efetivação de maneira diversa daquela defendida pelas normas constitucionais e infraconstitucionais.

Ressalta Regina Maria Fonseca Muniz que:

A par das mencionadas medidas constitucionais, o cidadão, apoiado no art. $5^{\circ}, \mathrm{XXXV}$, da Constituição Federal, que consagra o direito e a garantia fundamental de se socorrer do Judiciário em caso de lesão ou grave ameaça a direito, deve buscar a satisfação dos seus direitos subjetivos. ${ }^{61}$

Desta maneira, mesmo que não haja qualquer ação especifica para que o cidadão defenda a efetivação de seu direito à educação, poderá ele acionar o Judiciário, exigindo que o mesmo aprecie o caso concreto e por se tratar de "direito fundamental e, portanto, do direito à educação, inserido no direito à vida, não pode deixar de aplicar as normas, devendo ditar a norma jurídica concreta, conferindo ao interessado o direito reclamado, segundo as instituições existentes" 62 .

O mandado de segurança poderá ser também, impetrado contra a autoridade competente pela realização da educação em face do descumprimento de tal direito. Ele é uma medida comumente utilizada quando não há vagas suficientes nas escolas para atender a todos. A pessoa lesada impetra o mandado de segurança com a finalidade de garantir sua vaga e a possibilidade de estudar.

\footnotetext{
${ }^{60}$ MOTTA, Elias de Oliveira. Direito educacional e educação no século XXI: incluindo comentários à nova lei de diretrizes e bases da educação nacional e legislação conexa e complementar. Brasília: UNESCO, 1997.p.228.

${ }^{61}$ MUNIZ, Regina Maria Fonseca. O direito à educação. Rio de Janeiro: Renovar, 2002.p.118.

${ }^{62}$ MUNIZ, Regina Maria Fonseca. O direito à educação. Rio de Janeiro: Renovar, 2002.p.118.
} 
Mostra-se, ainda, possível a utilização das ações que tutelam em geral os interesses individuais, coletivos e difusos (ação civil pública), “com natureza antecipatória, valendo destacar, ainda, as ações cautelares e as ações inibitórias, buscando a proteção das ameaças a direito" ${ }^{63}$.

Nota-se hoje, que a jurisprudência tem correspondido às necessidades da educação, e muitos são os julgados em que se nota a ação do judiciário para a preservação dos direitos constitucionais, principalmente, no que diz respeito à garantia de vagas no ensino fundamental, bem como ao cumprimento dos preceitos constitucionais traçados para a educação.

A omissão do Estado pode causar danos irreversíveis em face da importância do direito à educação, deste modo a atuação do judiciário se faz necessária para conter os abusos e as irresponsabilidades da administração pública na efetivação deste direito.

Entretanto, para isso é preciso que o Poder Judiciário seja acionado por aqueles que se sintam lesados em seu direito. A prática de fato desses mecanismos auxiliará para a garantia de uma educação de qualidade e que efetivamente atenda a toda a população.

\section{CONCLUSÃO}

Não restam dúvidas de que o direito à educação é essencial, não somente ao seu titular, mas também à realidade social, econômica e cultural na qual esse está inserido.

O presente trabalho buscou, além de ressaltar a importância e necessidade do direito à educação como colaboradora da formação psicológica, intelectual e moral de qualquer criança ou adolescente, analisar as normas constitucionais, com o escopo de questionar sua aplicação e efetivação no cotidiano da educação brasileira.

Do estudo das normas constitucionais, apreendeu-se que muitas normas que tratam do direito à educação (em seu sentido amplo) são reconhecidas como programáticas. A doutrina em grande parte entende que tais normas são de eficácia limitada, pois, aguardam providências do legislador infraconstitucional para possuírem eficácia total.

Entretanto, a questão principal não se resume às determinações abstratas presentes nos dispositivos constitucionais, pois, este é um caso em que as normas programáticas tratam de situação jurídica fundamental, já que o direito à educação é uma necessidade do indivíduo e,

\footnotetext{
${ }^{63}$ MUNIZ, Regina Maria Fonseca. O direito à educação. Rio de Janeiro: Renovar, 2002.p.123.
} 
portanto, um interesse juridicamente relevante. Desta maneira, a norma programática cria um vínculo com o legislador, com o administrador, e também com o juiz, pois, possui juridicidade e capacidade de tutelar qualquer interesse. Diante desta vinculação esses três entes do Poder Público devem atuar, cada qual na sua esfera, para o cumprimento de tais normas.

As normas programáticas que tratam do direito à educação, ainda que dependentes de norma infraconstitucional, estipulam situações subjetivas legitimas aos titulares de tal direito, que podem sim, a qualquer momento, exigir seu cumprimento. Mesmo sendo programas elas criam a possibilidade de que se exija uma prestação do Poder Público. O artigo 205 da Constituição Federal mostra-se como um bom exemplo de norma programática da qual surge um interesse legitimo aos cidadãos. Assim, no caso de sua não observação poderá o interessado buscar meios para que seu direito se concretize, devendo este acionar o poder judiciário para a tutela de seus interesses.

É neste momento, que a problemática muda de foco e começa a girar em torno dos limites com os quais a juridiciadade deve operar no momento de concretizar o direito à educação, que como já exposto, é dotado de normativiade pelo simples fato de ter sido reconhecido constitucionalmente.

Alguns dos meios para a busca deste direito são trazidos pela própria Constituição Federal, tais como: a Ação Direta de Inconstitucionalidade, que poderá ser utilizada contra a omissão legislativa ou até da administração, quando não regulamentarem ou não cumprirem, respectivamente, norma constitucional que dispõe sobre o direito à educação; o Mandado de Injunção, que caberá somente contra omissões, em casos concretos, daqueles responsáveis pela edição de norma que tutela, também, direitos constitucionais, cujo efeito será inter partes e a decisão gerará o dever de prestação obrigatória ao titular prejudicado.

Ademais, muitas normas constitucionais programáticas que tratam da educação já foram regulamentadas pelo legislador ordinário. A Lei de Diretrizes e Bases, citada neste trabalho é um dos exemplos de norma regulamentadora que tornou eficaz muitos dispositivos da Constituição quanto à educação - outras tantas surgiram com esta mesma função. Nestes casos de já regulamentação, quando não houver o cumprimento de tais normas infraconstitucionais pelo Administrativo, o titular também contará com um importante remédio constitucional para pleitear a realização de seu direito, é o Mandado de Segurança, que no caso do direito à educação é a medida mais comumente utilizada. 
Diante do exposto, como entender que, ainda hoje, o direito à educação não se efetiva, muitas vezes (salvo algumas exceções), em concordância com o que estipula a Constituição Federal, amparada pelas leis infraconstitucionais?

A efetivação do direito à educação pode ser vista atualmente como um círculo vicioso, no qual teoricamente muito se aplica e pouco se produz. Teoricamente, pois, se analisados com cautela os recursos disponíveis à educação não são poucos, além disso, a responsabilidade pelo ensino é dividida, principalmente, entre Estados e Municípios sem considerar a ajuda financeira dada pela União, conforme manda a Constituição.

Compreende-se, desta maneira, que a norma constitucional existe para ser aplicada, pois, não é pura técnica, e para isso dispõe de mecanismos jurisdicionais, capazes de lhe dar concretude. Sendo assim, o problema reside na efetividade destas normas. Destarte, a análise deve ser voltada para a forma de aplicação das mesmas.

Será que o Estado, como principal responsável pelo acesso e permanência de crianças e adolescentes nas escolas, está observando os princípios constitucionais e as normas infraconstitucionais no momento da efetivação do direito à educação?

E quanto aos recursos? Não são eles suficientemente capazes de garantir a efetivação dos princípios constitucionais e infraconstitucionais na educação?

$\mathrm{Na}$ realidade é o interesse, organização, disponibilidade e responsabilidade de prestar o ensino fundamental que fazem a diferença. Com a realização destes propósitos o cumprimento dos princípios constitucionais, tais como a qualidade, a igualdade de condições, o pluralismo de idéias, a gestão democrática, a formação para o trabalho e o desenvolvimento acontecerão como conseqüência.

A boa administração dos recursos, o compromisso com o serviço que está sendo prestado e a conscientização de sua importância para a comunidade mostram qualidade e progresso no ensino, como alguns casos de sucesso que existem no país. O aumento da responsabilidade do Município com a educação, também foi fato importante para a efetivação deste direito com uma maior observância da Constituição Federal.

Mas, para que se efetive tal direito como rege a Constituição, é importante que haja também a conscientização das famílias e, principalmente, dos alunos quanto à importância do ensino. Cabe ao Estado promover esta conscientização, mostrar à população através da valorização do ensino sua essencialidade. 
Por esse motivo, é que o programa "Bolsa Família" mostra-se interessante, mas muitas vezes é interpretado de maneira diversa pelas famílias que recebem o benefício, já que ao mesmo tempo em que o governo oferece ajuda de custo para que jovens e crianças frequente as escolas, ele se descuida da qualidade do ensino oferecido, o que propicia o baixo rendimento dos estudantes nas salas de aula.

Os recursos são indispensáveis para a realização da educação fundamental como manda as normas, contudo, a aplicação dos mesmos com honestidade e comprometimento ajudará na obtenção dos objetivos almejados pela Constituição.

Assim, faz-se necessária uma reforma na maneira de se olhar para a Constituição Federal. Reforçar a juridicidade de suas normas seria uma forma de também reforçar os direitos da pessoa humana, que são verdadeiras fontes de legitimação de um verdadeiro Estado Democrático de Direito.

É neste contexto de mudança de pensamento, que o judiciário assume papel de destaque como interprete da Constituição. Embora muitos autores defendam que o judiciário tem a função de resolver conflitos e não atuar como legislador (quando busca suprir as lacunas deixadas pelo legislador infraconstitucional), entende-se que ao agir desta maneira o judiciário não está legislando, mas sim, estará auxiliando o titular de um direito a pleitear sua realização, já que não é razoavelmente aceitável que por capricho do legislador ou do administrador, alguém deixe de ter acesso a direito que lhe é fundamental.

Contudo, embora essencial, o judiciário não é protagonista único nesta busca de concretização da Constituição. Todos os protagonistas sociais devem ter ciência de que uma sociedade democrática só se constrói com consciência cidadã e que somente a partir dela será possível buscar a efetivação dos direitos constitucionais em sua essência.

\section{REFERÊNCIAS}

AMARAL, Gustavo. Direito, escassez e escolha. Rio de Janeiro: Renovar, 2001.

ARISTÓTELES. A política. São Paulo: Martins Fontes, 1998.

BARROSO. Luis Roberto. Neoconstitucionalismo e constitucionalização do direito (o triunfo tardio do direito constitucional no Brasil). Revista brasileira de direto público - RBDP. $\mathrm{N}^{\circ} 11$, out/dez, 2005. Editora Fórum. 
. O direito constitucional e a efetividade de suas normas. Limites e possibilidades da constituição brasileira. 6. ed. Rio de Janeiro: Renovar, 2002.

BASTOS. Celso Ribeiro Bastos. MARTINS, Ives Gandra. Comentários à constituição do Brasil. São Paulo: Saraiva, 1998.v.8.

BOBBIO, Norberto. Era dos direitos. Rio de Janeiro: Campus, 1992.

BRAGA, Valeschka e Silva. Princípios da proporcionalidade e da razoabilidade. Curitiba: Juruá Editora, 2004.

CANOTILHO, Joaquim José Gomes de. Constituição dirigente e vinculação do legislador: contribuição para a compreensão das normas constitucionais programáticas. Coimbra - Portugal: Coimbra, 1983.

1997.

Direito Constitucional e Teoria da Constituição. 3. ed. Coimbra - Portugal: Almedina,

GARCIA, Maria. A nova lei de diretrizes e bases da educação nacional. In: Revista dos Tribunais. Cadernos de Direito Constitucional e Ciência Política. n.23.

GRAU, Eros. A constituição brasileira e as normas programáticas. Revista de Direito Constitucional e Ciência Política. Rio de Janeiro: Forense, 2001. n.4.

HESSE, Konrad. A força normativa da constituição. Porto Alegre: Sergio Antonio Fabris Editor, 1991.

MIRANDA, Jorge. Manual de direito constitucional. Coimbra - Portugal: Coimbra, 1991.t.II.

MORO, Sérgio Fernando. Desenvolvimento e efetivação judicial das normas constitucionais. São Paulo: Max Limonad, 2001.

MOTTA, Elias de Oliveira. Direito educacional e educação no século XXI: incluindo comentários à nova lei de diretrizes e bases da educação nacional e legislação conexa e complementar. Brasília: UNESCO, 1997.

MUNIZ, Regina Maria Fonseca. O direito à educação. Rio de Janeiro: Renovar, 2002.

PIOVESAN, Flávia. Proteção judicial contra omissões legislativas. 2. ed. São Paulo: Revista dos Tribunais, 2003.

SARLET, Ingo Wolfgang. A eficácia dos direitos fundamentais. Porto Alegre: Livraria do Advogado, 1998.

SILVA, Jose Afonso da. Aplicabilidade das normas constitucionais. 6. ed. São Paulo: Malheiros Editores, 2003. 
Comentário contextual à constituição.3.ed. São Paulo: Malheiros, 2007.

Curso de direito constitucional positivo. 24. ed. São Paulo: Malheiros, 2004.

SILVA, Virgilio Afonso da (org.). Interpretação Constitucional. São Paulo: Malheiros, 2005.

TORRES, Ricardo Lobo (Org). Teoria dos direitos fundamentais. Rio de Janeiro: Renovar, 1999. 